\title{
Entrevista com Sidney Chalhoub
}

\author{
Por Atílio Bergamini Jr. ${ }^{1}$
}

Sidney Chalhoub é professor do curso de História da Unicamp desde 1985 e atua como pesquisador do Centro de Pesquisa em História Social da Cultura (Cecult, na mesma universidade). Seus livros individuais são: Trabalho, lar e botequim (1986), Visões da liberdade: uma história das últimas décadas da escravidão na Corte (1990), Cidade febril: cortiços e epidemias na Corte imperial (1996), Machado de Assis, historiador (2003) e A força da escravidão: ilegalidade e costume no Brasil oitocentista (2012). Em parceria com outros pesquisadores organizou: A história contada: capitulos de história social da literatura no Brasil (1998), Artes e ofícios de curar no Brasil (2003), História em cousas miúdas: capitulos de história social da crônica no Brasil (2005) e Trabalhadores na cidade: cotidiano e cultura no Rio de Janeiro e em São Paulo, séculos XIX e XX (2009).

Desde Trabalho, lar e botequim, sua dissertação de mestrado, na qual aparecem referências a escritores como Lima Barreto, Chalhoub se vale de obras literárias para construir suas hipóteses como historiador. Em Visões da liberdade, tese de doutorado transformada em livro em 1990, iniciou um diálogo direto com pesquisadores da área da literatura, ao discutir as interpretações de John Gledson para uma crônica que Machado publicara logo após a abolição, na série "Bons dias!". O diálogo com pesquisadores da área de literatura talvez tenha sido mais intenso no período que seguiu a publicação de Machado de Assis historiador, atualmente referência obrigatória no campo de estudos a respeito do escritor fluminense.

1 Atílio Bergamini Junior - (Unicamp - Universidade Estadual de Campinas- Pós-doutorando no IEL-UNICAMP, vinculado ao projeto temático "A circulação transatlântica dos impressos e a globalização da cultura no século XIX” (FAPESP), sob supervisão de Márcia Abreu. Doutor em Literatura Brasileira pela UFRGS., 
Na entrevista aqui apresentada, Chalhoub discute seus métodos de pesquisa, de exposição, bem como localiza sua perspectiva quanto às possibilidades da pesquisa de crônicas do século XIX, tarefa que, segundo ele, exige reconhecer a singularidade do jornalismo do período, em que literatura, opinião e política eram campos bem menos especializados do que atualmente. Além disso, reflete a respeito do que chama de expulsão da imaginação (e da crônica) na imprensa brasileira contemporânea.

A entrevista foi gravada no dia 05 de agosto de 2013, no gabinete de Chalhoub, no Cecult, Unicamp. Ela foi editada a aproximadamente 1/3 do tamanho original. Agradecemos ao historiador por ter aberto espaço de sua agenda, pela generosidade e abertura ao diálogo. Além disso, como reconhecimento do trabalho realizado, agradecemos ao bolsista XXXXX Rodrigo XXXXX pela transcrição da entrevista.

Perguntas e respostas

AB: Percorrendo os teus livros e artigos, pode-se talvez construir uma série de traços com os quais o senhor costuma expor o que pensa em relação à crônica e ao modo de abordá-la desde a perspectiva do historiador social. Vou elencar alguns desses traços e gostaria que o senhor apontasse caso discorde ou ache que deve dar mais peso para um ou para outro. Primeiro, nas séries de crônicas de que Machado fez parte, a gente poderia falar em um narrador ou narrador-personagem, às vezes construído coletivamente, às vezes um pouco mais individualmente, mas um narrador ou narrador-personagem. Depois, o senhor parece muitas vezes apontar a proximidade ou a distância desse narrador em relação ao funcionário público Machado de Assis e, outras vezes, o Machado como cronista. O terceiro ponto seria a crônica como um documento. Outro traço seria a perspectiva na qual o estudo das crônicas entra: transição da escravidão para a sociedade de classes (no teu primeiro livro), o entendimento que os escravos tinham da liberdade (no segundo), o racismo e a higienização (no Cidade febril), a crítica à ideologia paternalista (em alguns dos capítulos do Machado historiador) e assim por diante. Por fim, a indeterminação como uma característica formal da crônica. Seriam elementos-chaves para entender teu processo de pensar a crônica e, caso não, por favor, exponha as discordâncias.

SC: Narrador, distância na relação autor-narrador, crônica como documento e indeterminação. Acho que todos esses elementos são, para mim, fundamentais para analisar qualquer série de crônicas. Porém, um proble- 
ma é que havia enorme diversidade na maneira de praticar a crônica, por isso essas questões serão respondidas talvez de maneira substancialmente diferente, a depender de que autor e série você trabalha. Às vezes, crônicas diferentes no interior da mesma série exigem abordagens singulares.

Por exemplo, no caso de Machado de Assis: em uma série como História de quinze dias, há um investimento na construção de um narrador. $\mathrm{Na}$ introdução de Leonardo Pereira ${ }^{2}$ ao volume comentado dessa série, ele mostra isso. No entanto, há algumas peças, às vezes uma parte dentro de uma determinada peça, uma determinada crônica, na qual você tem a nítida impressão de que Machado afasta o narrador e fala diretamente com o leitor, sobretudo nas horas em que ele homenageia pessoas que morreram. Você não tem a impressão de que há um narrador interposto ali. Isso também acontece algumas vezes em "A Semana", que, claramente, tem muito investimento na construção de um narrador. No entanto, ele nunca recebe nome, não aparece uma especificação clara dessa construção, como no caso das séries anteriores. Todavia, você vê ali claramente um investimento na construção do narrador e é possível notar características mais ou menos permanentes desse narrador. Mas, de vez em quando, o autor afasta o narrador e entra na série.

Há diversidade maior a respeito dessas características conforme você lê crônicas de outros autores. Às vezes parece que o autor utiliza pseudônimo porque essa é a prática, mas não há nenhuma distinção entre a voz dele, autor real, e a voz do autor fictício. Então, acho que há uma diversidade grande de possibilidades na investigação da crônica e a regra básica é que não existem fórmulas prévias.

Acho que as questões são essas: (1) você tem que se perguntar se há a construção de um narrador ficcional. (2) Você tem que se perguntar qual é a relação desse narrador com o autor, em termos de opiniões, de ideias e tudo mais. (3) Quanto ao caráter documental da crônica, eu diria que qualquer texto tem caráter documental. Isso é credo de historiador social. Não existe uma alienação tão intensa que coloque alguém fora da história. Por mais alienado que você seja, você vai ser alienado dentro da história em que você vive. Não há remédio. Pode haver remédio para tudo, menos para isso. Nesse sentido, o que o texto documenta é uma questão que também

2 Leonardo Affonso de Miranda Pereira. O volume organizado e prefaciado por ele é História de quinze dias. Campinas: Unicamp, 2009.

3 Série de crônicas que Machado de Assis escreveu entre 1892 e 1897 para o jornal Gazeta de Notícias. Os dois primeiros anos da série foram anotados e comentados por John Gledson: $A$ Semana. São Paulo: Hucitec, 1996. 
precisa ser abordada. (4) Por mais que eu defenda a ideia de que a crônica é um texto radicalmente literário nas suas ambições, no seu feitio etc., ela se caracteriza por ser uma obra em formação contínua, em relação com a história que ela comenta. Isso é uma característica da crônica, mas talvez seja interessante não radicalizar demais as diferenças entre crônica e outros textos literários. Por exemplo, o ato de escrever romance em folhetim podia colocar o autor numa relação com a contingência que, em alguma medida, pode lembrar a crônica. O escritor pode ter que se relacionar com as repercussões do texto que escreve e com os eventos que rodeiam a própria experiência da escrita. Então a indeterminação é uma característica muito forte na crônica, mas não significa que ela esteja ausente de outras práticas de escrita literária do período. Ela, de fato, pode estar presente em outros gêneros literários, no modo como eles eram produzidos, nas circunstâncias da imprensa do século XIX. Então é bom não radicalizar demais essa questão. Acho que as questões são essas, mas as respostas são indefinidas, dependendo de cada série de documentos que você vai analisar.

AB: Haveria, vamos dizer assim, uma palavra-chave para tratar da crônica, que o senhor acrescentaria a essas?

SC: Palavra-chave talvez não, mas acho que a gente só consegue formular um conceito de alguma coisa criando contrastes às vezes muito marcados em relação a outras coisas. Por exemplo, nos jornais do século XIX, uma característica do texto literário é a noção de ficção, ou seja, o pressuposto de que há uma relação instável entre a realidade e a representação dela. Não há intenção de transparência. No pacto de leitura, o leitor sabe que o texto será inventado, mesmo quando aquilo que é inventado está firmemente relacionado ao mundo no qual ele vive. Isso vale para a crônica, porque há o cronista inventado. Então, nas crônicas com o narrador ficcional caracterizado, o leitor não está esperando ler diretamente a opinião do autor. Tudo aquilo é inventado, portanto o leitor nunca é ingênuo, ele sabe que está entrando em um mundo imaginário, no qual, entretanto, se vai falar sobre o que aconteceu no parlamento ontem. O mundo imaginário se refere a debates que de fato aconteceram, faz referências a personagens que de fato existem, mesmo que a personagem narradora seja uma invenção e converse com outras personagens que inventa.

Nesse caso você tem um texto literário ficcional, porque o pacto de leitura é similar ao pacto de leitura de outros gêneros ficcionais. O leitor sabe o que está lendo. Sabe que a pretensão do texto que ele lê não é contar 
as coisas como realmente elas aconteceram, o que pode ser o protocolo de textos que estão nas colunas ao lado. O problema é que, ao ler as colunas ao lado, você encontra uma série de procedimentos de ficcionalização. Digamos que uma coluna de "Bons Dias!"” apareça ao lado de uma coluna que narre um crime qualquer. Essa coluna vai começar assim: "O ciúme, esse sentimento humano que há milênios causa enormes tragédias etc.". Você vai ler dez linhas, e não há fato, há um procedimento de ficcionalização que não está na ficção. Então, a gente não pode achar que os procedimentos de ficcionalização estão restritos aos textos de ficção. Assim como também nós sabemos que os procedimentos ou as pretensões de documentar não estão restritos aos textos de protocolo não ficcional, os textos que são frequentemente escritos com pretensão de documentar.

Essas tendências criam contrastes que ajudam a fazer uma espécie de tipologia dos textos, a conceituá-los ou a definir suas características fundamentais. Mas a coisa na verdade é muito mais confusa, muito mais indeterminada. Nesse sentido, é importante pesquisar cada vez mais a imprensa: ela concentra tipos muito variáveis de texto. E o exercício de examinar o protocolo dos diferentes tipos de texto que convivem num mesmo espaço material, folha ou jornal, é muito interessante.

Aliás, é interessante pensar como a experiência dessa diversidade textual é diferente do modo como se lê jornal hoje em dia. Hoje em dia você pergunta para os alunos quem lê jornal em papel. Numa turma de quarenta, quatro ou cinco levantam o braço. Significa que a experiência da leitura mudou completamente. Se você pega um jornal em papel, bem ou mal, ao pegar aquele objeto separado, você tem uma postura, inadvertidamente, de que ele é uma unidade, algum tipo de unidade. Você imagina que não é exatamente uma obra, como um livro, mas você imagina que há uma coerência prévia, a partir do fato de que aquele objeto está inteiro na sua mão. Você faz um exercício de dar coerência à coisa. Se eu perguntar para você o que é o Estado de São Paulo, você vai ter uma imagem dele que o torna diferente da Folha de São Paulo. Você pega um objeto e outro, você tem expectativas prévias diferentes.

A experiência da leitura na internet é muito diferente disso. Você está lendo um artigo num jornal qualquer e logo entra num link para outro lugar. Aquela unidade se dispersa numa rapidez impressionante, você começa a pular para várias unidades diferentes. Você já não pode ler com aquela expectativa de que há certa coerência nas coisas que você vai ler (uma coerência dada

4 Série de crônicas publicada por Machado na Gazeta de Notícias, em 1888 e 1889. John Gledson anotou e prefaciou a série: Bons Dias! Campinas: Unicamp, 2008. 
por uma unidade criada por aquele que, no jornal, vai ter sua equipe, vai ter seu critério editorial). Ao contrário, você vai ficar pulando rapidamente de assuntos, ou, no mesmo assunto, pulando para outras unidades.

AB: Em Trabalho, lar e botequim, o senhor abre um diálogo com o Florestan Fernandes, a respeito da agência que os escravos poderiam ter nas condições sociais escravistas. Conforme o senhor, a visão de Florestan Fernandes estaria perigosamente - o advérbio é teu - próxima daquela veiculada pelas elites. Esse debate se estende nos teus livros posteriores ao diálogo com trabalhos de Fernando Henrique Cardoso, John Gledson e Roberto Schwarz. Por isso, talvez a discussão a respeito da função dos narradores na crônica, que o senhor e John Gledson têm posto de pé, seja também uma discussão sobre noções de o que é a história, como ela deve ser entendida. Não parece ser uma questão meramente literária. Isso parece evidente quando o senhor, em Visões da liberdade, comenta que John Gledson queria apontar na crônica sobre o Pancrácio, de "Bons Dias!", a abolição da escravatura como um não-acontecimento. O senhor aponta que Machado aparentemente entendia a abolição como um horizonte de diversas ações, entre elas a visão do próprio senhor de escravos, que gostaria que ela fosse um não-acontecimento. Então gostaríamos que o senhor comentasse um pouco essas maneiras de representar a história da escravidão e suas relações com a interpretação literária.

SC: Em primeiro lugar, acho que há uma questão que dificulta às vezes a conversa entre historiadores e críticos literários: é a ideia de que é possível utilizar a história como uma espécie de âncora para interpretação dos significados das alegorias. $\mathrm{O}$ crítico literário, extremamente perspicaz e atento às múltiplas possibilidades de interpretação do texto literário, parece ter a tendência a postular uma determinada estabilidade do sentido da história. Quando Gledson interpreta alegorias históricas na obra do Machado, a visão de história que está subentendida é uma história que, uma vez sabida, está definitivamente determinada. Por isso ela serve como âncora. A mesma coisa no caso de Roberto Schwarz. É claro que as histórias que servem como âncora são diferentes em cada um deles, até porque o jeito de trabalhar é diferente: no caso do Gledson se busca, digamos, alegorias da história política, ou referências mais diretas à histórica política, já o Schwarz está mais interessado em uma representação estrutural da história e de como ela aparece nos textos ficcionais. Em ambos os casos, há o compartilhamento de uma noção de que o conhecimento histórico, uma vez atingido, está fechado. O que é muito estranho, até do ponto de vista da sofisticação desses 
autores, imaginar que possa haver uma disciplina, no caso a História, fora da história, ou seja, fora de um constante debate que refaz os sentidos dos próprios textos literários, porque você pode olhar para eles a partir de uma experiência histórica diferente. Então, os textos literários nunca terão uma estabilidade de sentido, entre vários motivos, porque sempre estarão sendo lidos a partir de uma perspectiva histórica que será sempre diferente.

A partir do tipo de História Social que me interessa foi possível ver problemas ou sentir certo incômodo em relação ao tipo de leitura do Schwarz, do Fernandes, do Fernando Henrique Cardoso, porque, curiosamente, ela recolocava um jeito de se referir aos escravos que foi muito importante no pensamento abolicionista no século XIX. Aliás, não é à toa que o Joaquim Nabuco era uma espécie de referência muito importante para todos esses autores. E qual era o projeto político do Nabuco? Para criar a ideia de que os abolicionistas falariam em nome dos escravos, Nabuco teorizou a ideia de que os escravos não tinham capacidade de ter voz própria. Ele inclusive considerava covardia fazer com que os escravos defendessem sua própria causa, porque eles estariam despreparados para fazê-lo e chamariam sobre si a repressão violenta das classes dominantes. Eles não teriam nem os instrumentos de poder para fazer valer sua vontade, nem saberiam como fazer isso. Então, a desqualificação política dos escravos é fundamental para que Nabuco crie a noção da missão dos abolicionistas. É por isso que - de acordo com essa visão - os escravos são desprovidos de família, a violência da escravidão os desumaniza, os torna incapazes politicamente e tudo mais. Tudo isso tem um sentido político muito concreto e muito importante nos anos 1880. O Nabuco buscava valorizar uma via legal e buscava instrumentalizar e mobilizar uma parte da opinião pública pela causa do fim da escravidão. Mas ele não queria mobilizar os escravos para lutarem por sua própria causa. Esse era o limite, digamos, uma característica de seu abolicionismo.

Aliás, e não se pode perder isso de vista, todas as maneiras de lutar contra a escravidão eram válidas e foram importantes. A de Nabuco foi fundamental. Mas isso é o enquadramento que ele tinha a respeito da questão. Quando você pega esse enquadramento, que é uma visão política específica, construída num momento de luta política determinada, e retira isso do contexto, a visão que se constrói sobre o escravo se transforma numa maneira cristalizada de representar a escravidão. Você, na verdade, acaba por reificar a visão do Nabuco, quer dizer, você a tira de sua historicidade, essencializando-a e naturalizando-a.

Por outro lado, essa maneira de ver as coisas, evidentemente, torna procedentes e importantes muitas das abordagens do Florestan Fernandes, 
do Roberto Schwarz, do John Gledson e do próprio Fernando Henrique Cardoso. Eu escrevi e vários outros historiadores escrevem sobre escravidão, debatem ou criticam essa visão, mas não se parte da noção que tudo que está ali esteja errado. Na verdade a análise do Schwarz, por exemplo, a respeito do narrador de Memórias póstumas de Brás Cubas, é excelente até onde ela vai. É claro que há aspectos que não foi possível tematizar, por causa do enquadramento teórico específico que ele tinha. Assim como o jeito como eu enquadro teoricamente as coisas me impede de ver uma porção de outras. Cabe aos outros mostrar o que fico sem ver. Mas você não pode reificar nenhuma interpretação da história como A História.

Esse é o problema, às vezes, que surge no diálogo com o crítico literário: às vezes ele busca que a história seja a âncora, dê segurança para as interpretações. A história não pode dar segurança nenhuma, para além da própria historicidade das interpretações. E, com isso, não estou querendo cair em nenhum tipo de relativismo. Essas visões parciais, historicamente condicionadas, são visões verdadeiras, mesmo porque elas estão submetidas a critérios de demonstração e prova. Não é porque uma visão parte da historicidade presente, da historicidade específica do sujeito do conhecimento, que faz com que essa visão seja, só por isso, válida. Para ser válida ela precisa ser acompanhada de um discurso de demonstração e prova que permita que aquilo que você vê sobre a história de outro tempo se torne plausível na experiência daqueles sujeitos, não só na sua experiência. Mesmo que aqueles sujeitos não entendam que a experiência histórica deles tinha aquele sentido, que retrospectivamente nós podemos atribuir às experiências deles. Nós não estamos condenados a saber sobre as sociedades do passado apenas aquilo que elas sabiam sobre elas próprias. Nós sabemos coisas sobre eles que eles não sabiam sobre eles próprios.

Nesse sentido, acho que o principal problema está nessa expectativa de que a história é contexto de alguma coisa. A história não é contexto de nada, porque ela não está fora de nada. Às vezes aparece muito desse tipo de coisa, quando você vai falar da história, você fala do contexto, e depois você vai falar da literatura. Esse jeito de pensar não leva a lugar nenhum. Reproduz essa noção da história como âncora, como segurança para o significado, e você trabalha com essa coisa meio esquizofrênica: o sentido do texto literário é muito polivalente e indeterminado, mas o sentido da história poderia ser único.

Além disso, se você for buscar o quadro teórico do qual Schwarz parte no Ao vencedor as batatas, verá que aquelas definições de escravidão, de favor, de liberalismo, são definições abstratas. A historiografia não entende 
mais que escravidão e trabalho livre são coisas opostas. Esse contraste de que o liberalismo produz trabalho livre e é incompatível com a escravidão - uma ideia central no raciocínio do Schwarz - não se sustenta. Não só porque historicamente várias sociedades escravistas abraçavam a ideologia liberal, mas pelo fato de que a última trincheira de defesa da escravidão foi o liberalismo. Você defendia a escravidão em nome da propriedade privada. Além disso, o liberalismo do século XVIII, XIX, ao invés de eliminar a escravidão e o trabalho compulsório, primeiro viveu longamente com a escravidão; segundo, substituiu a escravidão por outras formas de trabalho compulsório. O trabalho dito livre, em geral vinha acompanhado de sanções criminais ou de formas de servidão, como o endividamento, ou outras maneiras de restringir a liberdade do trabalhador. $\mathrm{O}$ grande problema da história ocidental no século XIX era imaginar um mundo sem escravidão ou sem trabalho compulsório. E esse problema não foi superado enquanto Machado viveu.

Aliás, não foi superado até hoje em dia, pois o novo liberalismo, o neoliberalismo, inventou novas formas de trabalho compulsório. Não é à toa que no mundo das relações trabalho as coisas que mais chamam atenção são as sweatshops. Ou seja, a terceirização da produção manufatureira em outros países que não os países do centro da Europa criou formas de trabalho compulsório ou análogo à escravidão no dito "terceiro mundo". A desregulação do trabalho e a retirada de direitos tornam o trabalho cada vez mais parecido ou análogo à escravidão, uma experiência comum no neoliberalismo. Então, mesmo essa noção de que havia escravidão e ela foi superada é uma noção puramente ideológica, mais uma peça de propaganda do que a realidade do que acontece em relações de trabalho no mundo inteiro no capitalismo.

Portanto, essas cisões muito rígidas que o Schwarz faz entre escravidão e trabalho livre, entre realidade brasileira e realidade europeia, entre favor e liberalismo, são noções abstratas demais.

Eu acho que o Schwarz tem o mérito de fazer as perguntas certas para entender a relação entre a forma literária e a historicidade dela, quer dizer, como a forma literária se relaciona com a historicidade dela, com a situação histórica na qual ela foi produzida. A resposta que ele dá é válida, considerando-se que a visão de século XIX que ele postula tem uma validade relativa, como qualquer tipo de visão (como também a minha visão tem uma validade relativa).

A leitura do Machado, do ponto de vista histórico, precisa incorporar essas diferentes visões da história na interpretação da literatura. Não so- 
mente a literatura é polissêmica, a história também é polissêmica. Essas polissemias têm que se relacionar. Não devemos excluir a polissemia no intuito de dar estabilidade de sentido aos textos literários.

AB: Vou ler dois trechos de um artigo que o senhor escreveu, depois fazer uma questão. Aqui o senhor está debatendo com o Sérgio Paulo Rouanet": "Sem duvidar da hipótese de que muito do humor das Memórias Póstumas se deva às ditas influências inglesas, shandianas ou outras, não se deve subestimar a riqueza da inserção de Machado de Assis na imprensa do período, em especial quanto à tradição do humor crítico dos costumes políticos, e de outros costumes também, políticos num sentido menos aparente, por isso talvez mais profundo e de maiores consequências na reprodução das injustiças sociais". O segundo trecho é: "A crônica machadiana da década de 1880, meu ponto de chegada, apropria-se do repertório satírico, em verso e prosa, das lutas políticas entre periodistas liberais e conservadores ao longo do Segundo Reinado. A derrota política marcava a fundo a trajetória dos liberais. Viviam da memória gloriosa da abdicação do primeiro imperador, tido por autoritário, adepto do liberalismo teórico, do romantismo prático". Esses trechos indicam um programa de pesquisa: fazer uma investigação do repertório satírico da imprensa. Eu queria que o senhor falasse um pouco sobre como seria a investigação desse repertório satírico. Qual o lugar da crônica nesse repertório satírico?

SC: Acho que, para fazer essa pesquisa, a melhor estratégia seria, ou é - e acho que tem uma quantidade grande de alunos que tem feito esse tipo de exercício - ler a obra literária nas suas publicações originais. Então, por exemplo, investi uma quantidade razoável de tempo nas Memórias de um sargento de milícias. Você vai ao Correio Mercantil, onde saem as Memórias durante mais de um ano. Tive uma aluna de Iniciação Científica que fez uma investigação inicial sobre isso. Acompanhá-la foi interessante.

Ela foi ao Correio Mercantil. As Memórias saíam num caderno de domingo, a Pacotilha, totalmente dedicada ao humor. Então o romance saía num caderno de domingo que era totalmente dedicado ao humor. Ele foi explicado em profundidade pelo Mamede Mustafa Jarouche, na sua tese de doutorado, que é uma tese riquíssima em termos de entender o entorno da publicação das Memórias de um sargento de milícias. Infelizmente, a tese

5 O trecho discute as hipóteses de Riso e melancolia: a forma shandiana em Sterne, Diderot, Xavier de Maistre, Almeida Garrett e Machado de Assis. São Paulo: Cia. das Letras, 2007. A referência ao artigo de Chalhoub é: "A crônica machadiana: problemas de interpretação, temas de pesquisa". In Remate de Males, n. 29, v. 2, jul-dez, 2009.

Organon, Porto Alegre, v. 28, n. 55, p. 203-218, jul./dez. 2013. 
não foi publicada e é difícil de obter, mas ele fez a introdução da edição das Memórias de um sargento de milícias pela Ateliê Editorial, e, ali, fala dessa cultura satírica da Pacotilha, do Correio Mercantil. Vê-se claramente que se está diante de um jornal que tem um carimbo liberal muito evidente. Lá estão os temas recorrentes da cultura política liberal: o antilusitanismo, por exemplo, é importante; a crítica aos excessos do Poder Absoluto; a maneira de ironizar as relações de compadrio, todas essas coisas que estão muito presentes na cultura política liberal.

Isso aparece também no texto do Joaquim Manuel de Macedo, Memórias do sobrinho do meu tio, por exemplo, quando o compadre Paciência, que é o próprio liberal, pensa os costumes políticos e os costumes sociais a partir de um ponto de vista liberal. Eu acho que essa era, em alguma medida, a turma do Machado. A visão política dele tinha um parentesco com essas visões liberais que atuaram no século XIX inteiro.

Claro que há nuances, que há diferenças. Só pra voltar ao Nabuco: o Machado tinha uma proximidade muito grande com o Nabuco, já nos anos 1880, não só depois dos anos 1890, quando eles foram cupinchas e tramavam juntos as eleições da Academia Brasileira de Letras. Mesmo nos anos 1880 , eles tinham uma proximidade política. Machado claramente apreciava o modo como Nabuco atuava naqueles anos de militância abolicionista. Mas tem horas que você vê que as visões não caminham juntas. Nas vozes ficcionais, Machado frequentemente elaborava representações sobre como superar a escravidão que não caberiam no discurso do burocrata, nem no discurso de Nabuco.

Isso é outra coisa. A gente está acostumado a pensar nas vozes narrativas como estáveis em função dos autores. Elas são estáveis em função do gênero do texto. Então, o mesmo autor, tratando do mesmo assunto, pode tratá-lo com significativas diferenças políticas, num discurso parlamentar, numa crônica, num romance, num parecer jurídico. Nesse sentido, às vezes, alguns autores como José de Alencar, por exemplo, que praticou todos esses tipos de texto, são interessantes para detectar nuances importantes no jeito de se posicionar sobre o mesmo assunto, dependendo do gênero de texto. É como se a forma do texto fosse uma fôrma que tornasse algumas coisas dizíveis e outras difíceis de dizer. Então, essa relação entre a forma e o conteúdo é fundamental, não só na análise da literatura, mas na análise de qualquer tipo de locução. Por isso que eu estou falando que a crônica tem a sua fôrma. Ela não é um gênero praticado no vácuo. Então ela tem um protocolo de humor. Mas quais são as fontes desse humor? Essa é a conversa com o Rouanet. Não estou dizendo que ele está errado. Pelo contrário, estou Organon, Porto Alegre, v. 28, n. 55, p. 203-218, jul./dez. 2013. 
convencido de que ele tá certo. Só que eu acho que a fôrma desse humor deve-se muito a essa cultura satírica e o ponto de vista nessa cultura satírica adotado pelos liberais. Evidentemente, portanto, há uma fôrma que é ao mesmo tempo formal e política. Porque evidentemente os conservadores têm a sua tradição satírica também, só que aí é uma forma na qual cabe outro tipo de conteúdo, outra visão da política. A fôrma na qual o humor da crônica machadiana é vazado é uma fôrma na qual o conteúdo, a tradição da sátira política, é fundamental. E a tradição da visão liberal é fundamental.

AB: Dois dos teus livros que estão mais próximos de pensar especificamente sobre crônicas, História contada $e$ História em cousas miúdas, são livros coletivos. Na introdução de História contada, o senhor e Leonardo Pereira se perguntam assim: "O que determina a fonte? Qual a lógica social do texto?". Ao mesmo tempo, há a questão, que tratamos anteriormente, da indeterminação como uma característica formal da crônica, talvez como uma característica da prática do cronista. Chama a atenção que convivam a pergunta "o que determina a fonte?" e essa ideia de indeterminação. Talvez o senhor pudesse falar um pouco sobre isso.

SC: Originalmente falei a respeito da indeterminação porque ela é muito importante no debate a respeito das características literárias da crônica, do narrador da crônica. Um dos fundamentos do Gledson para dizer que nas crônicas não há construção de um narrador ficcional, ou para achar que isso é menos importante do que eu penso ser, ou o Leonardo [Affonso de Miranda Pereira] pensar ser, nas crônicas do Machado em especial, é a ideia de que você não pode comparar um narrador como o Brás Cubas ou um narrador como o Dom Casmurro com um narrador das séries de crônicas, como o Lélio, o Policarpo - apesar de o Gledson nem entender que existe o Policarpo. ${ }^{6}$

6 O livro de Miranda Pereira que está na origem do debate é $O$ carnaval das letras: literatura e folia no Rio de Janeiro do século XIX. Campinas: Unicamp, 2004, originalmente dissertação de mestrado, de 1993, orientada por Maria Clementina Pereira Cunha. Chalhoub, no artigo anteriormente referido, "A crônica machadiana: problemas de interpretação e temas de pesquisa", debateu as posições de John Gledson a respeito da posição dos narradores nas séries de crônicas publicadas nos anos 1870 e 1880. No artigo, Chalhoub rebate a crítica feita por Gledson ao trabalho de Miranda Pereira. John Gledson comentou o debate na reedição da introdução à série "Bons dias!", em Por um novo Machado de Assis. São Paulo: Cia. das Letras, 2006, p. 134-187. Ver p. 158 e ss., bem como a nota 21, p. 403-4. Gledson critica a utilização do termo "narrador", que Miranda Pereira utilizou para descrever o ponto de vista articulado nas crônicas da série "Bons dias!". Além disso, discute a respeito da interpretação, por Chalhoub, do nome Pancrácio, na crônica publicada na série "Bons Dias!", logo após a abolição. 
Falar de indeterminação foi importante para deixar claro que a gente também não confunde esses narradores. Tanto em Memórias Póstumas quanto em Dom Casmurro, os dois narradores tem protocolo autobiográfico. Eles contam sua própria história a partir de um ponto de vista no final dessa história, teleológico. Eles controlam o sentido da história, do ponto de vista formal. Não existe nada para adiante deles, há uma finitude no texto deles. Quem lê sabe que aquilo acabou.

No caso do narrador das crônicas, é totalmente diferente. Você não sabe como a série vai acabar, você não sabe que história esse narrador contará na próxima semana, porque ninguém sabe o que acontecerá na próxima semana. Há uma indeterminação da construção do narrador que é muito diferente da construção do narrador no romance. Na experiência do leitor também há diferenças. Dito isso, não significa que os narradores das crônicas não tenham nome, não tenham características, modos de reagir aos assuntos que tenham certa coerência. Um trecho do doutorado de Ana Flávia Cernic Ramos sobre as "Balas de Estalo" faz um exercício muito interessante, que é mostrar como o narrador muda de ponto de vista em relação à política, antes e depois das discussões que deram origem à Lei dos Sexagenários (em 1885). A Gazeta de Notícias, no início, apoiou fortemente as propostas liberais do gabinete Dantas. ${ }^{7}$ As características iniciais que foram discutidas em torno do que seria essa lei foram apoiadas pelo jornal. E você vê o Lélio, nas "Balas de Estalo": ele tem uma opinião que certamente aproximava a posição daquele narrador da posição do próprio Machado. É a expectativa de que fosse feito alguma coisa a respeito da escravidão e as características que se anunciavam naquele projeto de lei pareciam positivas, em princípio. Depois há uma quebra de expectativa: o gabinete cai e a lei que aparece é uma verdadeira peça de adiamento, que foi uma grande decepção política para os liberais, para a Gazeta e para a gente que via as coisas como o Machado via. E o Lélio depois disso passa a ver a política de outro jeito, ele fica meio desiludido. Então você vê claramente, na série, como o narrador não é incoerente, como ele traduz a experiência da história. É um narrador sem fim, um narrador cujo fim não está inscrito no processo de escrita ou no processo de leitura. É nesse sentido que essa questão da indeterminação é fundamental. Não há nenhum problema em acompanhar a sofisticação daquela construção literária, incorporando nisso a indeterminação da história. Ocorre, então, um exercício interessante

7 O Gabinete liberal de Manuel Pinto de Souza Dantas atuou de 6 de junho de 1884 a 6 de maio de 1885. Foi sucedido pelo também liberal gabinete Saraiva, logo destituído, em agosto de 1885. A lei seria votada em setembro pelo gabinete conservador do Barão de Cotegipe. 
para o diálogo do historiador com o crítico literário, porque, nesse caso, o caráter literário do narrador não pode estar ancorado em nenhuma estabilidade de sentido histórico, porque a história está aberta por definição.

O outro lado é o que você falou: esses textos têm várias determinações, inclusive de projeto literário. Quando você inventa um narrador, atribui a ele um nome, dá a ele certas características, há determinações literárias na formulação desse narrador. Ele vai mudar ao longo do tempo, mas há um projeto original, que dá uma certa coerência à série. E, claro, o narrador estará determinado pelos assuntos históricos que vão emergir e pelo repertório de posições políticas disponíveis ao autor, a partir das quais o narrador é construído.

AB: A crônica tem sido pensada como uma especificidade brasileira, um gêenero brasileiro. Ela também é pensada em termos de um espaço de subjetividade dentro do jornal. Quando pensamos o jornalismo do século XIX no circuito da circulação mundial de notícias e textos, parece haver uma oportunidade para pensar a crônica nessa expansão internacional. Gostaria que o senhor refletisse sobre alguns dos limites de alguns dos enunciados naturalizados a respeito da crônica: o seu caráter brasileiro; o seu caráter subjetivo $e$, por fim, algumas projeções de características do jornalismo do século XX na leitura de crônicas do século XIX.

SC: Você conhece o livro da Marie-Ève Thérenty, La littérature au quotidien? ${ }^{8}$ Acho que é um livro bem interessante para entender essas mudanças.

Acho que o que acontece é que, vou usar essa palavra de novo porque acho que ela é importante, o protocolo do texto jornalístico de agora, o protocolo das características do jornal agora, é muito diferente do jornal do século XIX. No jornal de hoje em dia - o jornal que eu digo é aquele que você pega o papel, a unidade - as características dos textos estão claramente determinadas. As seções são delineadas, aparecem espaços constantes, há uma estabilidade de sentido nos vários textos que estão ali. $\mathrm{O}$ protocolo da informação é o protocolo da neutralidade, da objetividade e ela está claramente diferenciada da opinião. Na primeira página, estão as manchetes. Em jornais como um Estado de São Paulo, uma Folha de São Paulo, as páginas dois e três têm páginas de editorial, opinião abertamente

8 Marie-Ève Thérenty é professora de literatura na Universidade de Montpellier III, na França. Em 2009, colaborou na organização e escreveu diversos capítulos do importante volume La Civilisation du journal: histoire culturelle et littéraire de la presse au XIXe siècle. Paris: Nouveau-Monde. Em 2007 publicou La littérature au quotidien: poétiques journalistiques au XIXe siècle. Paris: Seuil.

Organon, Porto Alegre, v. 28, n. 55, p. 203-218, jul./dez. 2013. 
assumida como opinião, assinadas ou não. Se bem que haja um certo truque ideológico nisso, porque a não assinatura às vezes pode dar ao editorial certa pretensão de verdade (ele frequentemente quer dizer a verdade sobre as coisas, e, ao omitir a assinatura, ele pode passar a ideia de que aquilo não é opinião, mas é, digamos assim, o sentido das coisas).

Os jornais do século XIX não eram assim. No jornal de agora, a literatura ou a subjetividade, a subjetividade imaginária, o lugar da imaginação, da literatura, foi expulsa, ela só aparece naquela coluninha de crônica com o suspeito de sempre. Então, é o Zé Simão, o Verissimo. Tem outra coisa que dá para notar com muita clareza em "A Semana", do Machado. O Machado, em "A Semana", não parece inventar um narrador ficcional, ou, mais precisamente, ele o faz fingindo não fazer. Os leitores sabiam que era ele quem escrevia, no entanto, sabiam também que havia certa instabilidade entre autor e narrador. Não era preciso, digamos, inventar um pseudônimo para o leitor saber que está lendo literatura. Hoje, se você vai ler o Verissimo, apesar de a crônica estar assinada por ele, você não atribui de modo imediato as opiniões que estão na crônica ao autor dela. Você sabe que há alguma coisa literária, que confere instabilidade a essa relação. Mas nem todos os cronistas são assim. Quer dizer, acho que há cronistas que podiam estar na página dois, a página do editorial. $\mathrm{O}$ efeito do texto não é o efeito de criar uma distância entre o autor e o narrador, essa distância está encurtada, por assim dizer. .

Acho que há uma diversidade grande ainda hoje, assim como existia no século XIX. Mas o fundamental é que, no século XIX, esses espaços claramente diferenciados hoje --da informação, da opinião e da literatura- não estavam constituídos assim. Para começar, porque no século XIX o jornalista e o literato eram o mesmo autor, o mesmo agente produzia o texto jornalístico, o texto literário e os textos que você não sabe direito como definir. E está tudo no espaço do jornal, que era também o espaço da literatura.

Hoje em dia no jornal não há mais espaço para a literatura e, geralmente, os escritores não são jornalistas. Há jornalistas que escrevem esses livros que são resultados do exercício deles no jornalismo, mas não é natural, não é comum, o jornalista ser também literato, assim como não é comum que o literato seja jornalista, escreva outros tipos de texto. Os escritores, em geral, não vivem o cotidiano do jornalismo. Os autores vão sendo autores de um tipo de texto e não de outro. Isso não acontecia na imprensa do século XIX. Hoje em dia, acho que o jornal expulsou a imaginação literária de suas páginas e, com o protocolo de objetividade, expulsou a imaginação para valorizar a informação. Com isso, ele deixa entrar mais livremente 
a ideologia, torna invisíveis os critérios de escolha de que informação se publica. A pretensa objetividade expulsou a imaginação para deixar entrar a ideologia política mais rasteira. E isso é uma característica forte dos jornais, eles são ideologia em estado puro. Você pode prever com facilidade o que vai aparecer no Estadão e na Folha no ano que vem durante as eleições, por exemplo, ou como eles vão cobrir determinados assuntos. Tudo em nome da informação. É como se não houvesse interesse. A imaginação está ostensivamente expulsa dos jornais, enquanto no jornal do século XIX a imaginação não estava expulsa. Ao escrever uma coluna policial, o leitor supunha que o redator iria usar a imaginação. Isso que eu falei, de que o jornalista escrevia: "O ciúme causa grandes tragédias"... e antes de ele dizer qualquer coisa sobre o que aconteceu, ele já escreveu quinze linhas. Hoje em dia, em tese, há aquela escrita objetiva, direta.

A imaginação está expulsa ostensivamente. Mas o que está entrando aí no lugar da imaginação? Não é, certamente, uma maior objetividade. A Marie-Eve Thérenty conta essa história toda, na imprensa francesa.

O Machado tinha que mudar de série toda vez que achava que tinha que mudar de protocolo. Atualmente não têm isso. Então será que a crônica sobrevive mesmo nos jornais brasileiros de hoje em dia? Eu tenho dúvida. Será que é diferente do que se faz no exterior? Tenho dúvida. Se eu for pensar em crônica como texto no qual a imaginação impera, em que tudo está em suspenso, uma experiência de leitura parecida com a do romance ou do conto, eu acho que a experiência da leitura da crônica do Machado, aquela dos anos 1880,1890, é parecida com a experiência de ler qualquer outro tipo de literatura. Narrador, características específicas. Você entrava no texto sabendo que a citação da realidade estava em suspenso, o protocolo do texto não é a citação da realidade, mesmo que ele esteja comentando os eventos da semana. Não entro nos textos dos cronistas de hoje em dia com esse espírito. Raramente o texto me leva para esse espírito e, nesse sentido, não sei se continua a haver crônica no jornal brasileiro. Se existe, é tão periférico que pode ser realmente um estilo prestes a desaparecer. Pelo menos nos “jornalões”. Às vezes eu vejo uma manchete desses jornais mais populares e fico com a impressão: "Nossa, vai ter crônica aqui". Ali, o protocolo parece ser a crônica, mas eu não leio esses jornais, talvez devesse ler, para saber se ali acontece uma coisa diferente. Nos jornalões, que se pretendem levar a sério, eu acho que a crônica está praticamente expulsa, a imaginação está expulsa do espaço do jornal.

Recebido em: 21/11/2013. Aceito em: 21/11/2013. 